\title{
Stepwise dehydration of Cd-exchanged levyne: thermal stability and structural modifications
}

\author{
Georgia Cametti ${ }^{1}$ (I)
}

Received: 26 February 2021 / Accepted: 10 April 2021 / Published online: 12 May 2021

(c) The Author(s) 2021

\begin{abstract}
Zeolites show remarkable properties that can be tuned through cation exchange of their original extraframework content. In this respect, the response of the modified zeolite to the heating stimuli, in terms of structural modifications and thermal stability, can drastically change and is, therefore, an important factor to consider. In this study, the dehydration mechanism of a natural levyne previously exchanged with $\mathrm{Cd}^{2+}$ has been monitored in situ by single crystal X-ray diffraction. The initial dehydration trend between 50 and $175{ }^{\circ} \mathrm{C}$ is similar to that observed for the pristine material, levyne-Ca. The water loss is accompanied by extraframework cation migration within the zeolitic cavities and the unit-cell volume slightly contracts from $3503.8(1)$ to $3467.8(6) \AA^{3}$. From 200 to $250^{\circ} \mathrm{C}$, a pronounced drop of the unit-cell volume (-7\%) is observed. The dehydrated structure at $250^{\circ} \mathrm{C}$ corresponds to levyne $\mathrm{B}$ topology of natural levyne, characterized by the statistical rupture of the T-O-T bonds of the double six-ring membered cage. However, in contrast to levyne-Ca, the fraction of broken connections reached $50 \%$ instead of $37 \%$, and no additional structural modifications were detected up to $350{ }^{\circ} \mathrm{C}$. At $400{ }^{\circ} \mathrm{C}$, diffraction data pointed to the onset of the structural collapse. At this temperature, the measured unit-cell volume was $8 \%$ smaller compared to that of the RT structure. The corresponding contracted structure did not rehydrate after exposure to humid conditions for 21 days.
\end{abstract}

Keywords Levyne $\cdot$ Cd-zeolite $\cdot$ X-ray diffraction $\cdot$ Thermal stability

\section{Introduction}

The mineral levyne belongs to the group of zeolites. At room temperature (RT), levyne is rhombohedral, space group $R-3 m, \mathrm{a}_{\text {hex }}=13.35 c_{\text {hex }}=22.90 \AA, \mathrm{V}=3534 \AA^{3}$ (Gottardi and Galli 1985). The structure consists of interconnected tetrahedra $\mathrm{TO}_{4}\left(\mathrm{Ti}=\mathrm{Si}^{+4}, \mathrm{Al}^{3+}\right)$, which form single and double-membered rings stacked along the c-axis according to the AABCBBCAA sequence. The LEV framework type (Baerlocher et al. 2007) is built up by the so-called lev cavity $\left[4^{9} 6^{5} 8^{3}\right]$, which alternates with double six-rings (D6R) polyhedra $\left[4^{6} 6^{2}\right]$ along [001]. Two 8-memebered ring channels run perpendicular to this direction. The dominant extraframework (EF) cations are $\mathrm{Ca}$ and $\mathrm{Na}$ (Coombs et al. 1997), distributed along the threefold axis at different crystallographic positions that can vary depending on the sample

Georgia Cametti

georgia.cametti@geo.unibe.ch

1 Institute of Geological Sciences, Baltzerstrasse 1+3, 3012 Bern, Switzerland composition (Sacerdoti 1996; Gatta et al. 2005; Arletti et al. 2013; Ballirano and Cametti 2013).

The response of zeolites to external stimuli such as temperature, pressure and water vapour pressure depends on many factors and can significantly change according to the applied experimental conditions (Cruciani et al. 2006). In the past, the crystal structure of levyne-Ca was investigated at high pressure and high temperature. Gatta et al. (2005) and Gatta and Well (2006) reported an anomalous elastic behaviour of levyne-Ca, characterized by a change in the compression mechanism at $P>1 \mathrm{GPa}$. At high temperature, natural levyne experiences different transformations as a function of dehydration. These involve the contraction of the unit-cell volume, the statistical rupture of tetrahedral bonds $\mathrm{T}-\mathrm{O}-\mathrm{T}$ constituting the framework and the migration of $\mathrm{Ca}$ atoms within the zeolitic cavities (Arletti et al. 2013). Such transformations lead to the formation of two new structural topologies, levyne B (Arletti et al. 2013) and levyne B' (Cametti 2018) with different stacking sequence compared to the RT structure. The extent of the contraction of the unit-cell volume and the type of structural topology, 
which forms upon dehydration, depend on the experimental set-up and on the metal cations, which occupy the zeolitic cavities. For instance, levyne B' topology was observed only during in situ single crystal X-ray diffraction (SC-XRD) experiments at $275^{\circ} \mathrm{C}$, when the rupture of an additional $\mathrm{T}-\mathrm{O}-\mathrm{T}$ link of the framework began. In contrast, this transformation was not reported in the synchrotron $\mathrm{X}$-ray powder diffraction (SR-XRPD) study, where levyne B is maintained up to $700{ }^{\circ} \mathrm{C}$ (Arletti 2013). Moreover, recent studies on a fully Ag-exchanged natural levyne (Ag-LEV) (Cametti et al. 2020) indicated that with only $\mathrm{Ag}^{+}$as EF cation, the mineral undergoes a different dehydration path compared to levyne-Ca. Upon heating, the contraction of the unit-cell volume is less pronounced (4\% vs $5 \%$ for $\mathrm{Ca}-$ and $\mathrm{Ag}-\mathrm{LEV}$, respectively) and the levyne $\mathrm{B}^{\prime}$ topology, under the same experimental conditions used for levyne-Ca, does not form.

In the frame of a research aimed at investigating the role of the EF cations on the thermal stability of natural zeolites, we recently reported on the crystal structure of levyne after Cd-exchange in aqueous solution (Cametti et al. 2021). The RT structure of Cd-exchanged levyne (Cd-LEV), with chemical composition $\mathrm{Cd}_{2.6} \mathrm{Ca}_{0.6} \mathrm{Al}_{6.6} \mathrm{Si}_{11.4} \mathrm{O}_{36} \cdot 18.0 \mathrm{H}_{2} \mathrm{O}$, can still be described in $R-3 m$ space group and the distribution of the $\mathrm{EF}$ cations in the pores resembles that typical of levyne-Ca.

In the present study, the thermal stability of this $\mathrm{Cd}$ exchanged levyne is investigated by means of single crystal $\mathrm{X}$-ray diffraction (SC-XRD) experiments. The dehydration was followed in situ in order to track the structural modifications occurring upon heating. The results are then compared with those reported for the natural counterpart, levyne-Ca (Cametti 2018) and for the Ag-exchanged form, Ag-LEV (Cametti et al. 2020).

\section{Experimental methods}

The sample used in this study was the same described in Cametti et al. (2021) with average chemical composition $\mathrm{Cd}_{2.6} \mathrm{Ca}_{0.6} \mathrm{Al}_{6.6} \mathrm{Si}_{11.4} \mathrm{O}_{36} 18.0 \mathrm{H}_{2} \mathrm{O}$. A single crystal of CdLEV was glued on the top of a glass fibre and mounted on a goniometer head. X-ray diffraction experiments were carried out using a Bruker Apex II diffractometer equipped with a CCD detector, a MoK $\alpha$ radiation $(\lambda=0.71073 \AA)$ and an in house-built temperature regulated $\mathrm{N}_{2}$ blower. Diffraction data were collected from RT to $400{ }^{\circ} \mathrm{C}$ in steps of $25^{\circ} \mathrm{C}$. The crystal was equilibrated for at least 30 min before starting each data collection. Such experimental conditions can be regarded as dry and "close to equilibrium" and were the same applied in the high temperature (HT) study of the corresponding pristine material, levyne-Ca (Cametti 2018) and of the Ag-exchanged levyne (Cametti et al. 2020).

The Apex3 software package (Bruker AXS 2019) was used for the data reduction and absorption correction.
Structure solution was performed by direct methods using the software ShelxT (Sheldrick 2008). Structural refinements of each data set were carried out by Shelxl 2014 (Sheldrick 2015) using neutral atomic scattering factors. The extraframework species were located for each data set by difference-Fourier maps. Obverse-reverse twinning [-100 0-10 001] was observed in all data sets. From RT to $100^{\circ} \mathrm{C}$, the data were refined in space group $R-3 m$ (Merlino et al. 1975; Cametti, 2018). From $100{ }^{\circ} \mathrm{C}$ on, the analysis of the systematic extinctions and $R_{\text {sym }}$ values as determined by Xprep (Bruker AXS 2019) suggested space group $R-3$. However, due to the small differences between the $\mathrm{R}$ factors indicator of $R-3 m$ and $R-3$, test refinements were performed in both space groups. Finally, based on the $R_{\text {int }}, \mathrm{R} 1$ and weighting scheme values of the structural refinements, $R-3 m$ was maintained from 100 to $125^{\circ} \mathrm{C}$. Data sets collected at 150 and $175^{\circ} \mathrm{C}$ were refined in space group $R-3$. Crystallographic sites corresponding to symmetry-equivalent positions in $R$ $3 m$ were labelled by double digit (e.g. T1 and T11 in $R-3$ correspond to $\mathrm{T} 1$ in $R-3 m$ ). Between 200 and $250{ }^{\circ} \mathrm{C}$ the quality of the diffraction data, in terms of broadening and smearing of the reflections, significantly decreased leading to $R_{\text {int }}$ values $>10 \%$. Hence, in this temperature range only the unit-cell parameters were extracted. At $275{ }^{\circ} \mathrm{C}$, although the maximum resolution drastically dropped (maximum 2 theta $=46.24^{\circ}$ ) it was possible to solve and refine the structure in $R-3$ space group. In this structure, the new sites T1B, T11B, OB1 and OB2 appeared. These sites were interpreted due to statistical rupture of the T1-O2-T11 and T1-O3-T11 connections (see "Results" section). T1B and T11B were refined with Si scattering factors whereas OB1 and $\mathrm{OB} 2$ with $\mathrm{O}$ scattering factors. The occupancy of $\mathrm{T} 1$, T11, T1B, T11B, O2, O3, OB1 and OB2 was at first refined without constraints. After a first cycle of refinement, the occupancies of T1 and T11 converged to similar values and they were then constrained to be equal. Similarly, T1B and T11B occupancies approached (1-Occ.T1). A similar strategy was used to refine the population of the oxygen atoms $\mathrm{O} 2, \mathrm{O} 3, \mathrm{OB} 1$ and $\mathrm{OB} 2$ involved in the $\mathrm{T}-\mathrm{O}-\mathrm{T}$ breaking process. Finally, the following constraints were used: (Occ. $\mathrm{T} 1)=($ Occ.T11 $)=(1-$ Occ.T1B $)=(1-$ Occ.T11B $)=($ Occ. OB1 $)=(1-$ Occ. OB2 $)=($ Occ.O3 $)=(1-$ Occ.O2 $)$.

At $400{ }^{\circ} \mathrm{C}$, only the cell parameters were determined. The rehydration capacity of the dehydrated crystal used in SC-XRD measurements was tested by exposing it to humid conditions for 21 days at RT. After that, a new set of X-ray data was measured with the same diffractometer used for the HT experiments. Crystal data and refinement details of the structures at RT, 50, 100, 150, 175 and $275^{\circ} \mathrm{C}$ are summarized in Table 1. All structural drawings have been produced by the VESTA software (Momma and Izumi 2011). Crystallographic information files are provided as supporting information. 
Table 1 Crystal data and refinement parameters of Cd-LEV at RT, 50, 100, 150, 175 and $275^{\circ} \mathrm{C}$

\begin{tabular}{|c|c|c|c|c|c|c|}
\hline Crystal data & Cd-LEV RT & Cd-LEV 50 & Cd-LEV 100 & Cd-LEV 150 & Cd-LEV 175 & Cd-LEV 275 \\
\hline$a(\AA)$ & 13.4199(19) & $13.3930(7)$ & $13.2593(6)$ & $13.1451(6)$ & $13.1177(9)$ & $12.6260(11)$ \\
\hline$c(\AA)$ & $22.465(5)$ & $22.3519(15)$ & $22.7333(14)$ & $23.1673(13)$ & $23.271(2)$ & $23.513(2)$ \\
\hline$V\left(\AA^{3}\right)$ & $3503.8(12)$ & $3472.2(4)$ & $3461.3(4)$ & $3466.8(4)$ & $3467.8(6)$ & $3246.1(6)$ \\
\hline$Z$ & 3 & 3 & 3 & 3 & 3 & 3 \\
\hline Space group & $R-3 m$ & $R-3 m$ & $R-3 m$ & $R-3$ & $R-3$ & $R-3$ \\
\hline $\begin{array}{l}\text { Refined chemical } \\
\text { formula }\end{array}$ & $\begin{array}{l}\mathrm{Cd}_{1.81} \mathrm{Ca}_{0.96}(\mathrm{Si} \\
\mathrm{Al})_{18} \mathrm{O}_{36} \cdot 21 \mathrm{H}_{2} \mathrm{O}\end{array}$ & $\begin{array}{l}\mathrm{Cd}_{2.03} \mathrm{Ca}_{0.92}(\mathrm{Si} \\
\mathrm{Al})_{18} \mathrm{O}_{36} \cdot 18 \mathrm{H}_{2} \mathrm{O}\end{array}$ & $\begin{array}{l}\mathrm{Cd}_{1.70} \mathrm{Ca}_{1.03}(\mathrm{Si} \\
\mathrm{Al})_{18} \mathrm{O}_{36} \cdot 11 \mathrm{H}_{2} \mathrm{O}\end{array}$ & $\begin{array}{l}\mathrm{Cd}_{1.93} \mathrm{Ca}_{0.93}(\mathrm{Si} \\
\mathrm{Al})_{18} \mathrm{O}_{36} \cdot 4.7 \mathrm{H}_{2} \mathrm{O}\end{array}$ & $\begin{array}{l}\mathrm{Cd}_{2.17} \mathrm{Ca}_{0.88}(\mathrm{Si} \\
\mathrm{Al})_{18} \mathrm{O}_{36} \cdot 0.3 \mathrm{H}_{2} \mathrm{O}\end{array}$ & $\begin{array}{l}\mathrm{Cd}_{2.10} \mathrm{Ca}_{1.24}(\mathrm{Si} \\
\mathrm{Al})_{18} \mathrm{O}_{36}\end{array}$ \\
\hline Crystal size (mm) & $0.10 \times 0.12 \times 0.13$ & $0.10 \times 0.12 \times 0.13$ & $0.10 \times 0.12 \times 0.13$ & $0.10 \times 0.12 \times 0.13$ & $0.10 \times 0.12 \times 0.13$ & $0.10 \times 0.12 \times 0.13$ \\
\hline \multicolumn{7}{|c|}{ Intensity measurement } \\
\hline Diffractometer & $\begin{array}{l}\text { BRUKER APEX } \\
\text { II SMART }\end{array}$ & $\begin{array}{l}\text { BRUKER APEX } \\
\text { II SMART }\end{array}$ & $\begin{array}{l}\text { BRUKER APEX } \\
\text { II SMART }\end{array}$ & $\begin{array}{l}\text { BRUKER APEX } \\
\text { II SMART }\end{array}$ & $\begin{array}{l}\text { BRUKER APEX } \\
\text { II SMART }\end{array}$ & $\begin{array}{l}\text { BRUKER APEX II } \\
\text { SMART }\end{array}$ \\
\hline $\mathrm{X}$-ray radiation & $\begin{array}{l}\mathrm{MoK} \alpha \\
\quad \lambda=0.71073 \AA\end{array}$ & $\begin{array}{l}\text { MoK } \alpha \\
\quad \lambda=0.71073 \AA\end{array}$ & $\begin{array}{l}\mathrm{MoK} \alpha \\
\quad \lambda=0.71073 \AA\end{array}$ & $\begin{array}{l}\text { MoK } \alpha \\
\quad \lambda=0.71073 \AA\end{array}$ & $\begin{array}{l}\mathrm{MoK} \alpha \\
\lambda=0.71073 \AA\end{array}$ & $\begin{array}{l}\mathrm{MoK} \alpha \\
\quad \lambda=0.71073 \AA\end{array}$ \\
\hline $\mathrm{X}$-ray power & $50 \mathrm{kV}, 30 \mathrm{~mA}$ & $50 \mathrm{kV}, 30 \mathrm{~mA}$ & $50 \mathrm{kV}, 30 \mathrm{~mA}$ & $50 \mathrm{kV}, 30 \mathrm{~mA}$ & $50 \mathrm{kV}, 30 \mathrm{~mA}$ & $50 \mathrm{kV}, 30 \mathrm{~mA}$ \\
\hline Monochromator & Graphite & Graphite & Graphite & Graphite & Graphite & Graphite \\
\hline Temperature $\left({ }^{\circ} \mathrm{C}\right)$ & 25 & 50 & 100 & 150 & 175 & 275 \\
\hline Exposure time (s) & 10 & 10 & 10 & 10 & 10 & 10 \\
\hline $\operatorname{Max} .2 \theta\left(^{\circ}\right)$ & 54.53 & 55.58 & 52.52 & 51.58 & 49.61 & 47.96 \\
\hline \multirow[t]{3}{*}{ Index ranges } & $-15 \leq h \leq 14$ & $-15 \leq h \leq 14$ & $-15 \leq h \leq 13$ & $-15 \leq h \leq 13$ & $-15 \leq h \leq 13$ & $-14 \leq h \leq 14$ \\
\hline & $-17 \leq k \leq 17$ & $-17 \leq k \leq 17$ & $-16 \leq k \leq 16$ & $-15 \leq k \leq 15$ & $-15 \leq k \leq 15$ & $-14 \leq k \leq 14$ \\
\hline & $-28 \leq l \leq 26$ & $-26 \leq l \leq 29$ & $-28 \leq l \leq 26$ & $-28 \leq l \leq 26$ & $-27 \leq l \leq 25$ & $-26 \leq l \leq 24$ \\
\hline $\begin{array}{l}\text { No. of measured } \\
\text { reflections }\end{array}$ & 10,576 & 10,646 & 10,118 & 9839 & 9259 & 8412 \\
\hline $\begin{array}{l}\text { No. of unique } \\
\text { reflections }\end{array}$ & 989 & 1036 & 897 & 1484 & 1332 & 1135 \\
\hline $\begin{array}{l}\text { No. of observed } \\
\text { reflections } \\
I>2 \sigma(I)\end{array}$ & 897 & 912 & 774 & 1169 & 1042 & 610 \\
\hline \multicolumn{7}{|l|}{ Structure refinement } \\
\hline $\begin{array}{l}\text { No. of parame- } \\
\text { ters used in the } \\
\text { refinement }\end{array}$ & 79 & 79 & 94 & 135 & 114 & 90 \\
\hline$R$ (int) & 0.0625 & 0.0530 & 0.0536 & 0.0663 & 0.0614 & 0.0884 \\
\hline$R(\sigma)$ & 0.0304 & 0.0281 & 0.0261 & 0.0445 & 0.0431 & 0.0614 \\
\hline GooF & 1.176 & 1.176 & 1.134 & 1.139 & 1.124 & 1.476 \\
\hline $\mathrm{R} 1, I>2 \sigma(I)$ & 0.0609 & 0.0556 & 0.0712 & 0.0798 & 0.0861 & 0.1568 \\
\hline $\mathrm{R} 1$, all data & 0.0662 & 0.0622 & 0.0799 & 0.0973 & 0.1040 & 0.2108 \\
\hline wR2 (on $F^{2}$ ) & 0.1853 & 0.1621 & 0.1981 & 0.2229 & 0.2444 & 0.4367 \\
\hline $\begin{array}{l}\Delta \rho_{\max }\left(\mathrm{e}^{-3}\right) \\
\text { close to }\end{array}$ & $1.26 \mathrm{C} 5$ & $2.23 \mathrm{C} 5$ & $0.90 \mathrm{~W} 4$ & $0.82 \mathrm{C} 6$ & $0.98 \mathrm{C} 8$ & 0.98 C6 \\
\hline $\begin{array}{l}\Delta \rho_{\min }\left(-\mathrm{e}^{\circ} \AA^{-3}\right) \\
\text { close to }\end{array}$ & $-0.75 \mathrm{C} 4$ & $-1.26 \mathrm{C} 5$ & $-1.48 \mathrm{C} 1 \mathrm{~A}$ & $-1.06 \mathrm{~W} 3$ & $-0.93 \mathrm{CW} 2 \mathrm{~A}$ & $-1.30 \mathrm{C} 3$ \\
\hline BASF & $0.074(6)$ & $0.057(5)$ & $0.074(8)$ & $0.108(8)$ & $0.138(9)$ & - \\
\hline
\end{tabular}

\section{Results and discussion}

The crystal structure of Cd-LEV at RT (Table S1) is in agreement with that determined in our previous study (Cametti et al. 2021). Minor differences are found in the distribution of the EF cations. $\mathrm{C} 1$ is split over two positions, $\mathrm{C} 1(\mathrm{Occ} .=0.32(8))$ and $\mathrm{C} 1 \mathrm{~A}(\mathrm{Occ} .=0.48(8))$, with total occupancy equal to that determined for $\mathrm{C} 1$ in Cametti et al. 2021. Ca atoms are found at $\mathrm{C} 3$ site and, in addition, at $\mathrm{C} 4$ site (not present in Cametti et al. 2021). This tiny rearrangement of the $\mathrm{Cd}$ and $\mathrm{Ca}$ atoms also lead to a shifted position of the $\mathrm{H}_{2} \mathrm{O}$ at the W3 site, whereas no significant differences are found for $\mathrm{W} 1, \mathrm{~W} 2$ and W4. Their atomic coordinates are in agreement with those previously reported for Cd-LEV (Cametti et al. 2021). 


\section{Unit-cell parameter variation as a function of temperature}

The change of the unit-cell parameters as a function of temperature is reported in Fig. 1. Corresponding values of the unit-cell volume trend of levyne-Ca (Cametti 2018) and AgLEV (Cametti et al. 2020) are also shown for comparison (Fig. 1a). Upon heating, the simultaneous expansion and contraction along the c- and a-axis (Fig. 1b), respectively, causes an overall decrease of the unit-cell volume. At first, a tiny contraction occurs from 25 to $125^{\circ} \mathrm{C}$, when the volume decreases by approximately $1 \%$ if compared to that measured at RT. A more pronounced change is observed form 175 to $250{ }^{\circ} \mathrm{C}$, when the reduction amounts to $7 \%$. Such value is significantly higher compared to that of both levyne-Ca and $\mathrm{Ag}$-LEV at corresponding temperatures. As a reminder, the
Fig. 1 Unit-cell volume (a) and cell parameters (b) trend of $\mathrm{Cd}$-exchanged levyne as a function of increasing temperature. Corresponding values of natural levyne (levyne-Ca) (Cametti 2018) and Ag-exchanged levyne (Cametti et al. 2020) are also displayed (a) for comparison
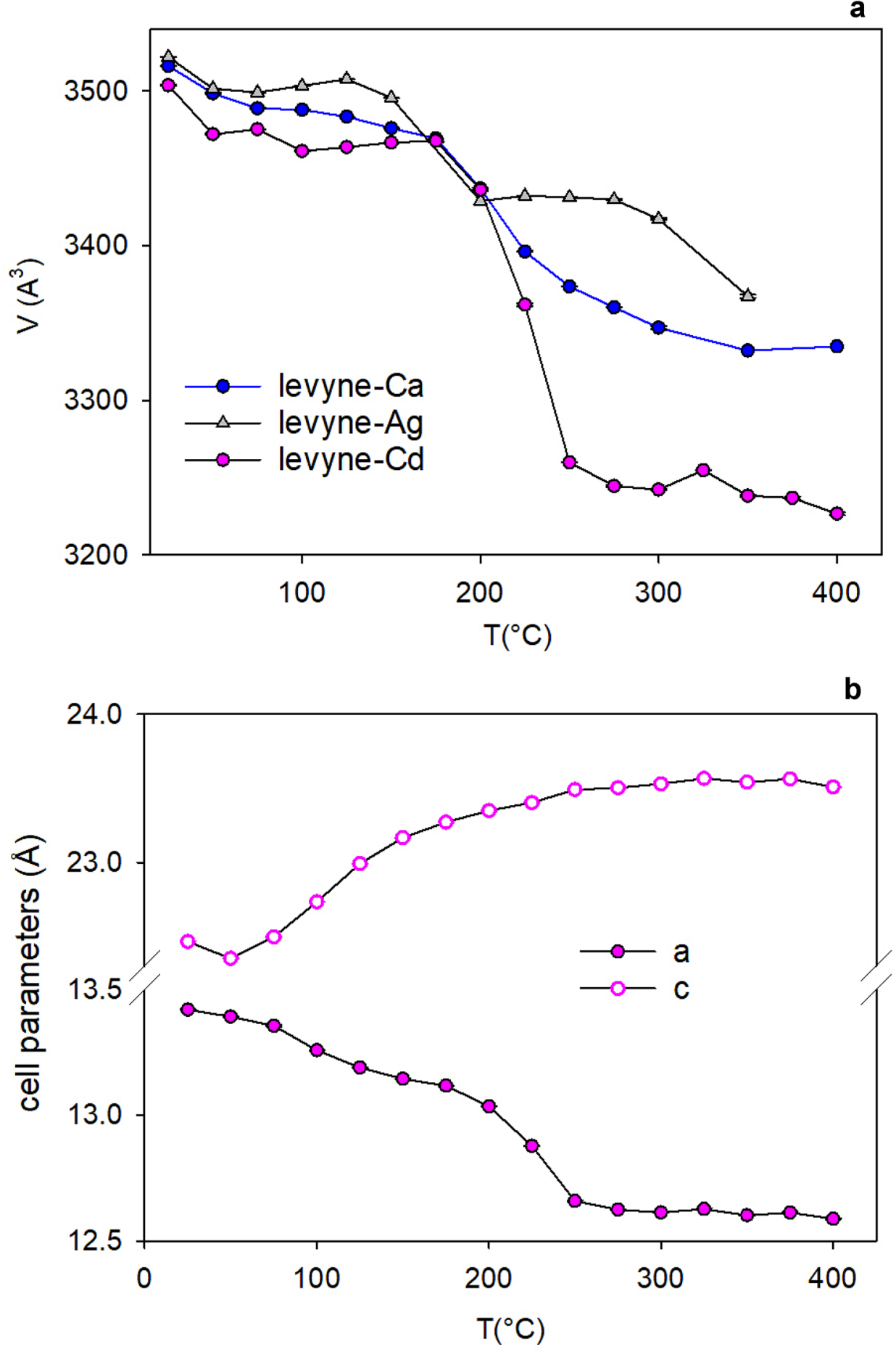
data reported in this study were collected under the same experimental conditions used for the other cationic forms. At $400{ }^{\circ} \mathrm{C}$, the unit-cell volume further decreases, reaching a total contraction of $8 \%$ with respect to the RT structure.

\section{Structural modifications upon heating}

The dehydration of Cd-exchanged levyne starts at $50{ }^{\circ} \mathrm{C}$, when part of the $\mathrm{H}_{2} \mathrm{O}$ at W2, W3 and W4 sites is released. In contrast, the $\mathrm{W} 1$ site remains fully occupied (Table 2). The water loss is accompanied by a change in the Ca distribution and Ca completely migrates to the $\mathrm{C} 3$ site $($ Occ. $=0.46(3))$, emptying $\mathrm{C} 4$. The $\mathrm{H}_{2} \mathrm{O}$ at $\mathrm{W} 2, \mathrm{~W} 3$ and $\mathrm{W} 4$ also readjust their positions, which result in a more disordered configuration (Fig. 2a).

The dehydration proceeds with the gradual depletion of the W1, W2, W3 and $\mathrm{W} 4$ sites and at $100{ }^{\circ} \mathrm{C}$, the content of structural $\mathrm{H}_{2} \mathrm{O}$ decreases to $11 \mathrm{H}_{2} \mathrm{O}$ pfu (Table 3). This decrease is accompanied by an increase of the disorder of the extra framework species. $\mathrm{Ca}$ and $\mathrm{Cd}$ start migrating toward the wall of the lev cavity at the $\mathrm{CW} 2$ and $\mathrm{C} 8$ sites, respectively (Fig. 2b). However, the high structural disorder makes complex the unequivocal assignment of $\mathrm{Ca}$ and $\mathrm{H}_{2} \mathrm{O}$, which spread over low occupied sites close to each other (Table 3). From this temperature on, electron density was detected at the centre of the double six-membered ring cages refined with $\mathrm{Cd}$ atomic scattering factor. The position of this site corresponds to that of $\mathrm{C} 6$ and $\mathrm{Ag} 1$ in the hightemperature structures of levyne-Ca (Cametti 2018) and AgLEV (Cametti et al. 2020), respectively. Upon heating, the occupancy at C6 gradually increases, indicating that, similar to levyne-Ca and Ag-LEV, part of the EF cations approaches the D6R due to dehydration.

At $150{ }^{\circ} \mathrm{C}$, a significant relocation of the $\mathrm{EF}$ cations takes place. $\mathrm{Ca}$ at $\mathrm{C} 3$ completely moves to the middle of the eight-membered ring windows of the lev cavity, at the CW2, CW2A and CW2B sites (Table 4, Fig. 2c). In addition, the migration of $\mathrm{Cd}$ inside the D6R cage continue and the occupancy of $\mathrm{C} 6$ reaches $30 \%$. Residual $\mathrm{H}_{2} \mathrm{O}$ content (approximately $5 \mathrm{H}_{2} \mathrm{O} \mathrm{pfu}$ ) is retained at $\mathrm{W} 1, \mathrm{~W} 2$, W2B and $\mathrm{W} 3$ sites. At $175^{\circ} \mathrm{C}$, the increasing structural disorder hampers a clear determination of the EF-cations $/ \mathrm{H}_{2} \mathrm{O}$ distribution. The refined content of structural $\mathrm{H}_{2} \mathrm{O}$ amounts to $0.3 \mathrm{H}_{2} \mathrm{O}$ pfu that is found exclusively at $\mathrm{W} 2$ site. However, it cannot be excluded that some $\mathrm{H}_{2} \mathrm{O}$ might be present also at the CW2 and CW2A sites (Table 5), as suggested by the slightly higher value of refined $\mathrm{Ca}$ atoms (i.e. 0.9 vs $0.6 \mathrm{apfu}$ based on the chemical composition of this sample).

Between 200 and $250{ }^{\circ} \mathrm{C}$, in correspondence of the pronounced drop of the unit-cell volume (Fig. 1a), the interpretation of the diffraction data was complicated by the strong smearing and broadening of the reflections (Fig. S1), the intensity of which significantly decreased. Thus, a meaningful solution of these structures was not possible and only the cell parameters were determined. At $275{ }^{\circ} \mathrm{C}$, although a high $R_{\text {int }}(8.84 \%)$, the structure could be solved and refined in space group $R-3$. This high- temperature structure, described in the next paragraph, is assumed to be completely dehydrated.
Table 2 Atom coordinates, occupancy and atomic displacement parameters of Cd-LEV at $50{ }^{\circ} \mathrm{C}$

\begin{tabular}{lllllll}
\hline Site & $\begin{array}{l}\text { Scattering } \\
\text { factor }\end{array}$ & $x$ & $y$ & $z$ & Occ & $U^{\text {eq }}\left(\AA^{2}\right)$ \\
\hline T1 & $\mathrm{Si}$ & $0.43827(11)$ & $0.10482(11)$ & $0.40503(6)$ & 1 & $0.0156(4)$ \\
$\mathrm{T} 2$ & $\mathrm{Si}$ & $0.23721(13)$ & 0 & 0.5 & 1 & $0.0142(5)$ \\
$\mathrm{O} 1$ & $\mathrm{O}$ & $0.3168(3)$ & $0.0251(4)$ & $0.44051(18)$ & 1 & $0.0321(10)$ \\
$\mathrm{O} 2$ & $\mathrm{O}$ & $0.4937(5)$ & $0.2469(3)$ & $0.4206(2)$ & 1 & $0.0273(12)$ \\
O3 & $\mathrm{O}$ & $0.5367(2)$ & $0.0735(5)$ & $0.4282(2)$ & 1 & $0.0260(12)$ \\
O4 & $\mathrm{O}$ & $0.4122(5)$ & $0.0789(5)$ & 0.3333 & 1 & $0.0295(13)$ \\
O5 & $\mathrm{O}$ & $0.1085(3)$ & $-0.1085(3)$ & $0.4845(3)$ & 1 & $0.0321(13)$ \\
Extrafram & & & & & \\
$\mathrm{C} 1$ & $\mathrm{Cd}$ & 0.6667 & 0.3333 & $0.47716(5)$ & $0.785(7)$ & $0.0260(5)$ \\
$\mathrm{C} 3$ & $\mathrm{Ca}$ & 0 & 0 & $0.3962(12)$ & $0.46(3)$ & $0.165(13)^{\mathrm{a}}$ \\
$\mathrm{C} 5$ & $\mathrm{Cd}$ & 0 & 0 & 0.5 & $0.460(8)$ & $0.0217(10)^{\mathrm{a}}$ \\
W1 & $\mathrm{O}$ & $0.5922(3)$ & $0.1843(7)$ & $0.5470(4)$ & 1 & $0.070(3)$ \\
W2 & $\mathrm{O}$ & $0.1507(13)$ & $-0.0829(13)$ & $0.3767(7)$ & $0.300(19)$ & $0.043(6)^{\mathrm{a}}$ \\
W2A & $\mathrm{O}$ & $0.144(4)$ & $-0.052(4)$ & $0.327(2)$ & $0.37(2)$ & $0.2^{\mathrm{b}}$ \\
W3 & $\mathrm{O}$ & $0.161(5)$ & $0.080(3)$ & $0.343(3)$ & $0.29(4)$ & $0.13(3)^{\mathrm{a}}$ \\
W4 & $\mathrm{O}$ & $0.125(3)$ & $-0.125(3)$ & $0.276(3)$ & $0.39(4)$ & $0.2^{\mathrm{b}}$ \\
\hline
\end{tabular}

${ }^{\mathrm{a}} \mathrm{U}$ isotropic

${ }^{\mathrm{b}}$ Fixed 


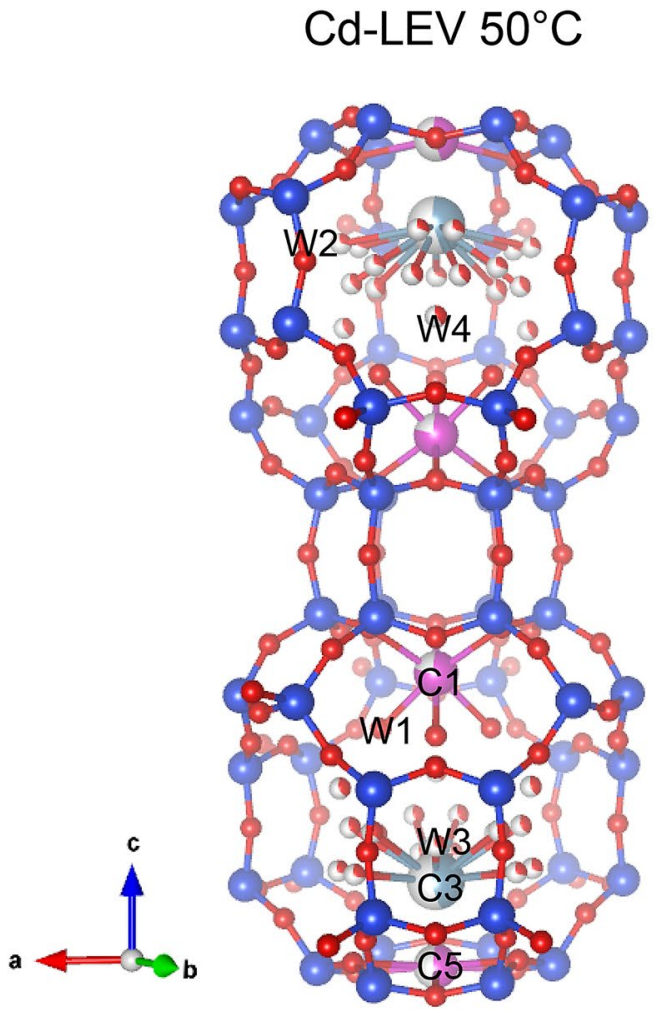

a

\section{Cd-LEV $100^{\circ} \mathrm{C}$}

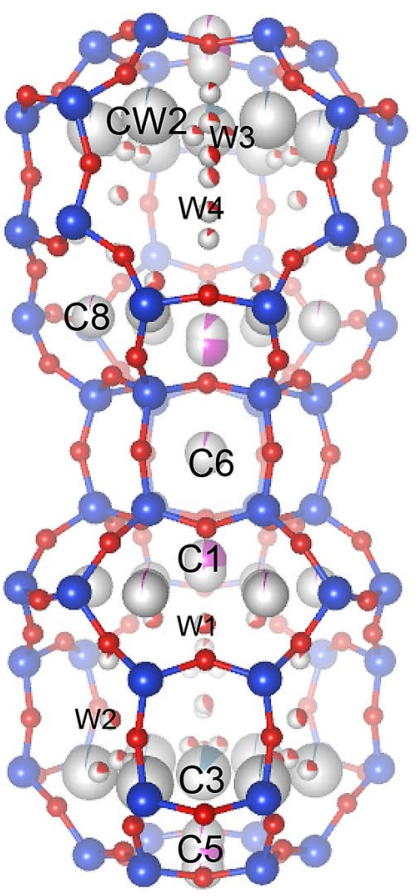

b
Cd-LEV $150^{\circ} \mathrm{C}$

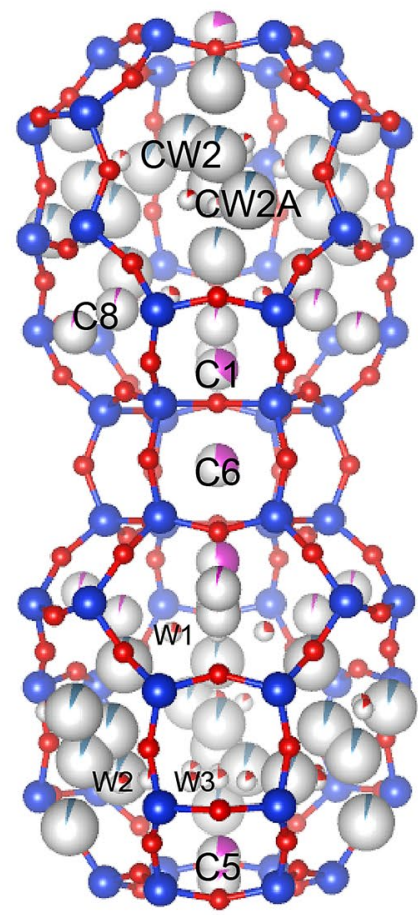

C
Fig. 2 Crystal structures of Cd-exchanged levyne at 50, 100 and 150 ${ }^{\circ} \mathrm{C}$. $\mathrm{Si}$ and $\mathrm{O}$ atoms are reported as blue and red spheres, respectively. $\mathrm{Cd}$ atoms are displayed in pink and $\mathrm{Ca}$ in light blue. Partial colour of

\section{The dehydrated structure of $\mathrm{Cd}$-exchanged levyne at $275^{\circ} \mathrm{C}$}

The contracted phase of Cd-LEV has a structural topology similar to that of levyne-Ca between 200 and $250{ }^{\circ} \mathrm{C}$. This structure is characterized by the statistical rupture of the $\mathrm{T}-\mathrm{O}-\mathrm{T}$ connections $(\mathrm{T} 1-\mathrm{O} 2-\mathrm{T} 11$ and $\mathrm{T} 1-\mathrm{O} 3-\mathrm{T} 11)$ of the D6R tetrahedra (Fig. 3a, Table 6). This mechanism involves the partial migration of $\mathrm{T} 1$ and $\mathrm{T} 11$ sites toward new position (T1B and T11B), with corresponding formation of two new tetrahedra with oxygen apices OB1 and OB2. Since this is a statistical process, two topologies coexist at high temperature: the original levyne (LEV) and the levyne B (Arletti et al.2013). The latter, which originates if only the new tetrahedral sites (i.e. $\mathrm{T} 1 \mathrm{~B}$ and $\mathrm{T} 11 \mathrm{~B}$ ) and $\mathrm{T} 2$ are considered, has $\mathrm{ABABCBCAC}$ stacking sequence (Fig. 3b). According to the structural refinement of Cd-LEV, $50 \%$ of the original tetrahedral sites ( $\mathrm{T} 1$ and $\mathrm{T} 11)$ migrated to the new positions T1B and T11B. The EF cations spread mainly along the threefold axis and residual $\mathrm{Cd}$ is found close to the wall of the lev cavity at C2, C7 and C8 sites (Table 6). Since it was not possible to monitor the structural changes between 200 the spheres corresponds to the refined partial-occupancy of the crystallographic sites

and $250{ }^{\circ} \mathrm{C}$, it remains enigmatic whether the rupture, similar to levyne-Ca, already began at lower temperatures and gradually increased up to $275^{\circ} \mathrm{C}$, or it was a more abrupt change. A plausible hypothesis is that the strong smearing and broadening of the reflections along the c-axis (Fig. S1) observed at $200{ }^{\circ} \mathrm{C}$, might be associated with the onset of the breaking process.

To check if this structural configuration is maintained at higher temperature, tentative refinements were performed on the structures at 350 and $375^{\circ} \mathrm{C}$. Although the low quality of the data, characterized by low resolution, no additional changes with respect the structure at $275^{\circ} \mathrm{C}$ were noticed. As an example, the refined parameters of the structure at 350 ${ }^{\circ} \mathrm{C}$ are reported in Table S2a, b.

Diffraction data at $400{ }^{\circ} \mathrm{C}$ (Fig. 4a) consisted of very broad reflections with a maximum resolution of $1.0 \AA$, pointing out the onset of the structural collapse. The estimated unit-cell volume determined at this temperature was 3226(1) $\AA^{3}$. The determination of the correct unit-cell parameters was complicated not only because of the additional damping of the atomic scattering-factors at high temperature but also because of the strong smearing and splitting of the 
Table 3 Atom coordinates, occupancy and atomic displacement parameters of Cd-LEV at $100{ }^{\circ} \mathrm{C}$

\begin{tabular}{lllllll}
\hline Site & Scattering & $x$ & $y$ & $z$ & Occ & $U^{\text {eq }}\left(\AA^{2}\right)$ \\
& factor & & & & & \\
\hline $\mathrm{T} 1$ & $\mathrm{Si}$ & $0.43342(15)$ & $0.10003(16)$ & $0.40245(7)$ & 1 & $0.0230(6)$ \\
$\mathrm{T} 2$ & $\mathrm{Si}$ & $0.23966(17)$ & 0 & 0.5 & 1 & $0.0194(6)$ \\
$\mathrm{O} 1$ & $\mathrm{O}$ & $0.3175(5)$ & $0.0178(5)$ & $0.4416(2)$ & 1 & $0.0500(16)$ \\
$\mathrm{O} 2$ & $\mathrm{O}$ & $0.4866(8)$ & $0.2433(4)$ & $0.4168(4)$ & 1 & $0.049(2)$ \\
$\mathrm{O} 3$ & $\mathrm{O}$ & $0.5362(4)$ & $0.0723(8)$ & $0.4240(3)$ & 1 & $0.046(2)$ \\
O4 & $\mathrm{O}$ & $0.4015(7)$ & $0.0681(7)$ & 0.3333 & 1 & $0.046(2)$ \\
O5 & $\mathrm{O}$ & $0.1104(4)$ & $-0.1104(4)$ & $0.4884(4)$ & 1 & $0.053(2)$ \\
Extraframewk & & & & & \\
$\mathrm{C} 1$ & $\mathrm{Cd}$ & 0.6667 & 0.3333 & $0.4671(6)$ & $0.53(5)$ & $0.0349(14)$ \\
$\mathrm{C} 1 \mathrm{~A}$ & $\mathrm{Cd}$ & 0.6667 & 0.3333 & $0.481(3)$ & $0.11(5)$ & $0.028(8)$ \\
$\mathrm{C} 3$ & $\mathrm{Ca}$ & 0 & 0 & $0.400(2)$ & $0.13(2)$ & $0.074(18)$ \\
$\mathrm{C} 5$ & $\mathrm{Cd}$ & 0 & 0 & 0.5 & $0.29(3)$ & $0.023(3)$ \\
$\mathrm{C} 5 \mathrm{~A}$ & $\mathrm{Cd}$ & 0 & 0 & $0.481(3)$ & $0.049(16)$ & $0.009(12)$ \\
$\mathrm{C} 6$ & $\mathrm{Cd}$ & 0.6667 & 0.3333 & 0.3333 & $0.039(7)$ & $0.005(11)$ \\
$\mathrm{C} 8$ & $\mathrm{Cd}$ & $0.428(3)$ & $0.093(3)$ & $0.5001(17)$ & $0.013(3)$ & $0.030(14)$ \\
$\mathrm{CW} 2$ & $\mathrm{Ca}$ & $0.239(5)$ & $0.000(5)$ & $0.398(2)$ & $0.026(7)$ & $0.029(19)$ \\
W1 & $\mathrm{O}$ & $0.5927(8)$ & $0.1854(15)$ & $0.5422(7)$ & $0.64(3)$ & $0.069(7)$ \\
W2 & $\mathrm{O}$ & $0.129(3)$ & $-0.129(3)$ & $0.326(3)$ & $0.40(3)$ & $0.2^{\mathrm{b}}$ \\
W2A & $\mathrm{O}$ & $0.144(2)$ & $-0.144(2)$ & $0.3887(19)$ & $0.24(4)$ & $0.064(19)$ \\
W4 & $\mathrm{O}$ & $0.201(3)$ & $-0.201(3)$ & $0.414(3)$ & $0.12(3)$ & $0.04(2)$ \\
W3 & $\mathrm{O}$ & $0.076(2)$ & $-0.1399(18)$ & $0.3784(9)$ & $0.24(2)$ & $0.040(9)$ \\
\hline
\end{tabular}

${ }^{\mathrm{a}} \mathrm{U}$ isotropic

${ }^{b}$ fixed

reflections (Fig. 4a). Such a contracted structure, as expected from the extent of the structural changes, is not able to reabsorb water. Diffraction data collected on the crystal used for the HT measurements and subsequently exposed to high humidity conditions at room temperature were limited to $2 \theta=41.7^{\circ}$ and are characterized by smeared and weak reflections (Fig. 4b). The unit-cell volume (3198.8(9) $\AA^{3}$ ) was comparable with that obtained for the structure at 400 ${ }^{\circ} \mathrm{C}$, confirming that it could not re-hydrate.

\section{Differences with levyne- $\mathrm{Ca}$ and Ag-exchanged levyne}

The structural evolution of Cd-LEV upon continuous heating can be summarized by the following two steps: (i) initial dehydration with corresponding diffusion of the EF cations within the zeolitic cavities; (ii) pronounced contraction of the unit-cell volume associated with the rupture of $50 \%$ of the T-O-T bonds constituting the D6R cage. This step leads the so-called levyne B topology (Arletti et al. 2013). Thus, differently from the pristine material levyne-Ca (Cametti,
2018), no additional transition to the levyne B'phase occurs in Cd-exchanged levyne.

In levyne-Ca, this transformation is associated with the breaking of an additional $\mathrm{T}-\mathrm{O}-\mathrm{T}$ bridge of the framework (T2-O5-T2), which starts at $275{ }^{\circ} \mathrm{C}$ in correspondence of the loss of residual $\mathrm{H}_{2} \mathrm{O}$. It may be argued that, in levyne-Cd, the onset of the breaking of an additional $\mathrm{T}-\mathrm{O}-\mathrm{T}$ was not detectable due to the quality of the diffraction data (Table 1). However, two arguments support a different transformation path:

- in levyne-Ca, at $300{ }^{\circ} \mathrm{C}$, the migration of $(\mathrm{Si}, \mathrm{Al})$ atoms toward the new T1B site amounted to $37 \%$, differently from Cd-LEV where at $275^{\circ} \mathrm{C}$ the population of the new $\mathrm{T}$ sites (T1B and T11B) is $50 \%$;

- the pronounced difference (from $200{ }^{\circ} \mathrm{C}$ on) between the unit-cell volume curves (Fig. 1a) indicates that in Cd-LEV the dehydration process is not only shifted toward lower temperatures (e.g. the unit-cell volume of the structure at $225^{\circ} \mathrm{C}$ corresponds to that of levyne-Ca at $275^{\circ} \mathrm{C}$ ), but also more drastic in terms of structural contraction. Thus, it is plausible that such behaviour is associated with different phase transformations. 
Table 4 Atom coordinates, occupancy and atomic displacement parameters of Cd-LEV at $150{ }^{\circ} \mathrm{C}$
Table 5 Atom coordinates, occupancy and atomic displacement parameters of Cd-LEV at $175^{\circ} \mathrm{C}$

\begin{tabular}{|c|c|c|c|c|c|c|}
\hline$\overline{\text { Site }}$ & $\begin{array}{l}\text { Scattering } \\
\text { factor }\end{array}$ & $x$ & $y$ & $z$ & Occ & $U^{\text {eq }}\left(\AA^{2}\right)$ \\
\hline $\mathrm{T} 1$ & $\mathrm{Si}$ & $0.66709(18)$ & $0.09596(19)$ & $0.89947(9)$ & 1 & $0.0340(6)$ \\
\hline $\mathrm{T} 11$ & $\mathrm{Si}$ & $0.57114(19)$ & $0.90418(19)$ & $0.10057(9)$ & 1 & $0.0340(6)$ \\
\hline $\mathrm{T} 2$ & $\mathrm{Si}$ & $0.75980(16)$ & $0.00016(17)$ & $0.99997(9)$ & 1 & $0.0294(6)$ \\
\hline $\mathrm{O} 1$ & $\mathrm{O}$ & $0.7037(7)$ & $0.0238(7)$ & $0.9434(3)$ & 1 & $0.067(2)$ \\
\hline $\mathrm{O} 11$ & $\mathrm{O}$ & $0.6802(6)$ & $0.9766(7)$ & $0.0567(3)$ & 1 & $0.066(2)$ \\
\hline $\mathrm{O} 2$ & $\mathrm{O}$ & $0.7595(6)$ & $0.5190(7)$ & $0.9021(4)$ & 1 & $0.083(3)$ \\
\hline $\mathrm{O} 3$ & $\mathrm{O}$ & $0.5379(5)$ & $0.0753(6)$ & $0.9175(3)$ & 1 & $0.0538(17)$ \\
\hline $\mathrm{O} 4$ & $\mathrm{O}$ & $0.6669(5)$ & $0.0512(6)$ & $0.8334(2)$ & 1 & $0.0520(15)$ \\
\hline O5 & $\mathrm{O}$ & $0.5568(6)$ & $0.1138(8)$ & $0.3472(4)$ & 1 & $0.081(3)$ \\
\hline \multicolumn{7}{|c|}{ Extraframework $^{\mathrm{a}}$} \\
\hline $\mathrm{C} 1$ & $\mathrm{Cd}$ & 0.6667 & 0.3333 & $0.94951(19)$ & $0.381(6)$ & $0.0683(16)$ \\
\hline $\mathrm{C} 1 \mathrm{~A}$ & $\mathrm{Cd}$ & 0.6667 & 0.3333 & $0.004(3)$ & $0.036(8)$ & $0.11(3)$ \\
\hline C5 & $\mathrm{Cd}$ & 1 & 1 & 1 & $0.123(11)$ & $0.031(5)$ \\
\hline $\mathrm{C} 5 \mathrm{~A}$ & $\mathrm{Cd}$ & 1 & 1 & $0.0277(3)$ & $0.178(7)$ & $0.034(2)$ \\
\hline C6 & $\mathrm{Cd}$ & 0.6667 & 0.3333 & 0.8333 & $0.319(6)$ & $0.0295(14)$ \\
\hline $\mathrm{C} 8$ & $\mathrm{Cd}$ & $0.5283(13)$ & $0.4715(13)$ & $0.0150(6)$ & $0.049(3)$ & $0.054(5)$ \\
\hline CW2 & $\mathrm{Ca}$ & $0.484(7)$ & $0.964(6)$ & $0.484(3)$ & $0.067(12)$ & $0.14(4)$ \\
\hline CW2A & $\mathrm{Ca}$ & $0.488(3)$ & $0.099(3)$ & $0.4595(11)$ & $0.056(9)$ & $0.034(12)$ \\
\hline CW2B & $\mathrm{Ca}$ & $0.463(4)$ & $0.927(4)$ & $0.4058(18)$ & $0.032(4)$ & $0.03^{\mathrm{b}}$ \\
\hline W1 & $\mathrm{O}$ & $0.602(4)$ & $0.400(4)$ & $0.035(2)$ & $0.24(4)$ & $0.12(3)$ \\
\hline W2 & $\mathrm{O}$ & $0.609(3)$ & $0.101(2)$ & $0.4594(11)$ & $0.14(2)$ & $0.016(11)$ \\
\hline W2B & $\mathrm{O}$ & $0.529(4)$ & $0.061(4)$ & $0.4546(16)$ & $0.23(4)$ & $0.075(18)$ \\
\hline w3 & $\mathrm{O}$ & $0.961(8)$ & $0.039(8)$ & $0.119(3)$ & $0.17(2)$ & $0.15^{\mathrm{b}}$ \\
\hline
\end{tabular}

${ }^{\mathrm{a}} \mathrm{U}$ isotropic

${ }^{\mathrm{b}}$ fixed

\begin{tabular}{lllllll}
\hline Site & $\begin{array}{l}\text { Scattering } \\
\text { factor }\end{array}$ & $x$ & $y$ & $z$ & Occ & $U^{\mathrm{eq}}\left(\AA^{2}\right)$ \\
\hline $\mathrm{T} 1$ & $\mathrm{Si}$ & $0.6673(2)$ & $0.0949(2)$ & $0.89872(10)$ & 1 & $0.0279(7)$ \\
$\mathrm{T} 2$ & $\mathrm{Si}$ & $0.75902(19)$ & $0.00020(19)$ & $0.00006(10)$ & 1 & $0.0231(7)$ \\
$\mathrm{T} 11$ & $\mathrm{Si}$ & $0.5725(2)$ & $0.9051(2)$ & $0.10124(11)$ & 1 & $0.0286(7)$ \\
O1 & $\mathrm{O}$ & $0.7025(8)$ & $0.0232(8)$ & $0.9438(3)$ & 1 & $0.061(2)$ \\
O11 & $\mathrm{O}$ & $0.6788(7)$ & $0.9764(8)$ & $0.0560(3)$ & 1 & $0.061(2)$ \\
O2 & $\mathrm{O}$ & $0.7600(7)$ & $0.5203(8)$ & $0.9004(5)$ & 1 & $0.074(3)$ \\
O3 & $\mathrm{O}$ & $0.5375(6)$ & $0.0755(7)$ & $0.9166(3)$ & 1 & $0.050(2)$ \\
O4 & $\mathrm{O}$ & $0.6671(6)$ & $0.0484(7)$ & $0.8330(3)$ & 1 & $0.0468(18)$ \\
O5 & $\mathrm{O}$ & $0.5574(7)$ & $0.1155(9)$ & $0.3465(4)$ & 1 & $0.074(3)$ \\
Extraframewn & & & & \\
$\mathrm{C} 1$ & $\mathrm{Cd}$ & 0.6667 & 0.3333 & $0.94403(16)$ & $0.387(7)$ & $0.0536(16)$ \\
$\mathrm{C} 1 \mathrm{~A}$ & $\mathrm{Cd}$ & 0.6667 & 0.3333 & $0.002(3)$ & $0.075(7)$ & $0.18^{\mathrm{b}}$ \\
$\mathrm{C} 5$ & $\mathrm{Cd}$ & 1 & 1 & $0.991(3)$ & $0.08(2)$ & $0.019(5)$ \\
$\mathrm{C} 5 \mathrm{~A}$ & $\mathrm{Cd}$ & 1 & 1 & $0.9713(14)$ & $0.17(2)$ & $0.029(3)$ \\
$\mathrm{C} 6$ & $\mathrm{Cd}$ & 0.6667 & 0.3333 & 0.8333 & $0.306(7)$ & $0.0276(19)$ \\
$\mathrm{C} 8$ & $\mathrm{Cd}$ & $0.4715(9)$ & $0.9428(9)$ & $0.9848(4)$ & $0.075(3)$ & $0.039(4)$ \\
CW2 & $\mathrm{Ca}$ & $0.716(5)$ & $0.852(5)$ & $0.870(2)$ & $0.118(10)$ & $0.15^{\mathrm{b}}$ \\
CW2A & $\mathrm{Ca}$ & $0.765(4)$ & $0.939(5)$ & $0.874(2)$ & $0.028(8)$ & $0.01(2)$ \\
W2 & $\mathrm{O}$ & $0.587(11)$ & $0.792(11)$ & $0.928(5)$ & $0.053(15)$ & $0.04^{\mathrm{b}}$ \\
\hline
\end{tabular}

${ }^{\mathrm{a}} \mathrm{U}$ isotropic

${ }^{\mathrm{b}}$ fixed 
Fig. 3 Crystal structure of Cdexchanged levyne at $275^{\circ} \mathrm{C}$. a Tetrahedral sites involved in the T-O-T breaking process are reported in cyan. Yellow sites (T1B and T11B) represent the new tetrahedral sites forming as a consequence of the $\mathrm{T}-\mathrm{O}-\mathrm{T}$ rupture. b Structural topology (levyne B) of Cd-LEV at 275 ${ }^{\circ} \mathrm{C}$. The stacking sequence of the six-membered rings along $\mathrm{c}$ is also shown

\section{Cd-LEV $275^{\circ} \mathrm{C}$}

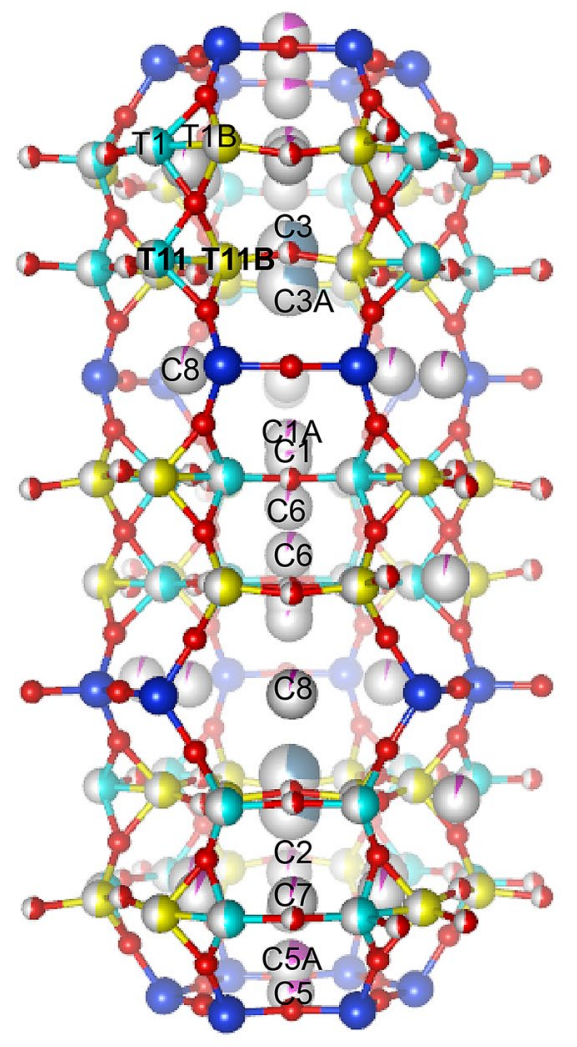

a

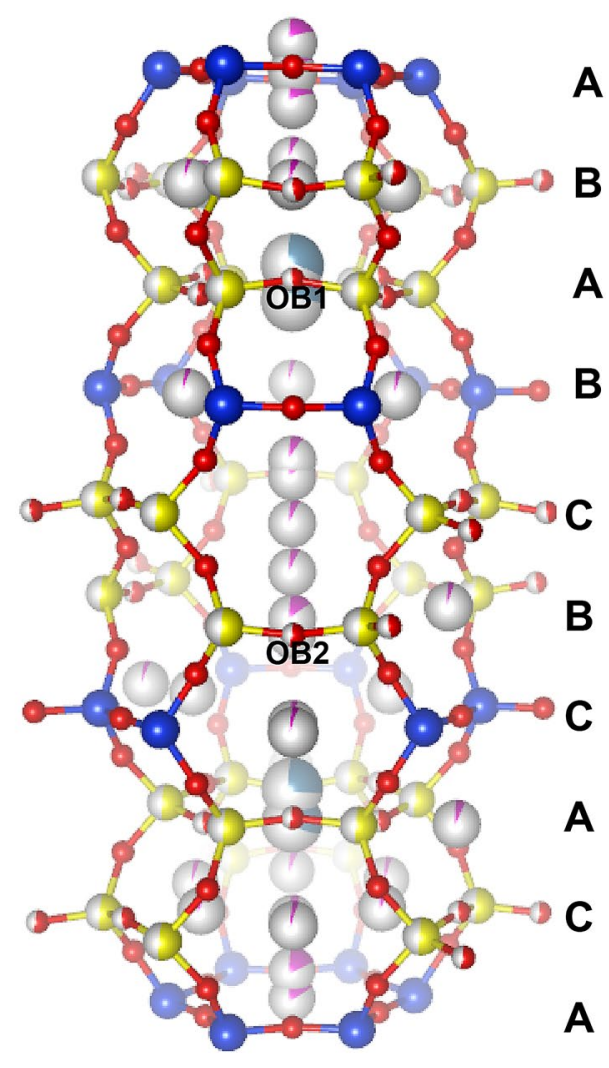

b
It has to be pointed out, at this point, that the drastic contraction of the unit cell of Cd-LEV is also related to a reduced thermal stability. Because of the smaller size (and higher ionic potential) of $\mathrm{Cd}^{2+}$ with respect to both $\mathrm{Ca}^{2+}$ and $\mathrm{Ag}^{+}$, it is reasonable that the thermal stability of Cd-LEV is lower compared to Ca- and Ag-LEV (Cruciani 2006). In this sense, $\mathrm{Cd}^{2+}$ exerts more strain on the framework that causes an earlier collapse with respect to Ca-LEV.

Interestingly, similar to Cd-LEV, upon dehydration levyne B' structure does not form in Ag-LEV too (Cametti et al. 2020). In that case, the absence of the B' topology was explained based on the $\mathrm{H}_{2} \mathrm{O}$ content of the RT structure. $\mathrm{Ag}$-LEV at ambient conditions contains less $\mathrm{H}_{2} \mathrm{O}$ compared to the pristine material; therefore, a second dehydration step, which would trigger the B-B' transition, does not take place. In Cd-LEV, the number of $\mathrm{H}_{2} \mathrm{O}$ pfu determined by the structural refinement (Table 1) is even slightly higher than the corresponding one in levyne-Ca. This is not surprising, considering that, in natural levyne-Ca, $\mathrm{Na}^{+}$and $\mathrm{K}^{+}$are also present as EF cations. In Cd-LEV, only divalent cations occupy the zeolitic cavities, where, consequently more $\mathrm{H}_{2} \mathrm{O}$ can be accommodated. Nevertheless, the structure does not experience a second $\mathrm{T}-\mathrm{O}-\mathrm{T}$ rupture. Thus, the missing transformation to B' must be related to specific properties of $\mathrm{Cd}^{2+}$.

In the SR-XRPD study by Arletti et al. (2013), this additional modification was not reported as well. In this case, the kinetic of the experiments (faster and far from the equilibrium) was responsible for the rapid water loss and the structure had not enough time to complete the transformations. In our SCXRD experiments, it seems like a similar mechanism is driving the dehydration of Cd-LEV. That is, a faster (compared to levyne-Ca) release of water may lead to a more abrupt dehydration and, therefore, to the absence of the B- $>$ B' transformation. The main difference between the trend of the unit-cell volume of levyne-Ca and Cd-LEV in Fig. 1a is certainly the stronger contraction of Cd-LEV. However, Cd-LEV is also characterized by a steeper unit-cell volume curve, pointing to 
Table 6 Atom coordinates, occupancy and atomic displacement parameters of Cd-LEV at $275{ }^{\circ} \mathrm{C}$

\begin{tabular}{|c|c|c|c|c|c|c|}
\hline Site & $\begin{array}{l}\text { Scattering } \\
\text { factor }\end{array}$ & $x$ & $y$ & $z$ & Occ & $U^{\text {iso }}\left(\AA^{2}\right)$ \\
\hline $\mathrm{T} 1$ & $\mathrm{Si}$ & $0.6696(6)$ & $0.0843(6)$ & $0.8902(3)$ & $0.465(4)^{\mathrm{a}}$ & $0.0718(16)^{b}$ \\
\hline $\mathrm{T} 1 \mathrm{~B}$ & $\mathrm{Si}$ & $0.5862(6)$ & $0.9184(6)$ & $0.8887(2)$ & $0.535(4)^{\mathrm{a}}$ & $0.0718(16)^{b}$ \\
\hline $\mathrm{T} 2$ & $\mathrm{Si}$ & $0.7489(3)$ & $1.0000(3)$ & $0.00005(11)$ & 1 & $0.0579(14)$ \\
\hline $\mathrm{T} 11$ & $\mathrm{Si}$ & $0.5851(6)$ & $0.9160(6)$ & $0.1097(3)$ & $0.465(4)^{\mathrm{a}}$ & $0.0718(16)^{b}$ \\
\hline T11B & $\mathrm{Si}$ & $0.6675(6)$ & $0.0814(6)$ & $0.1113(2)$ & $0.535(4)^{\mathrm{a}}$ & $0.0718(16)^{b}$ \\
\hline $\mathrm{O} 4$ & $\mathrm{O}$ & $0.6662(8)$ & $0.0095(10)$ & $0.8335(3)$ & 1 & $0.112(4)$ \\
\hline $\mathrm{O} 1$ & $\mathrm{O}$ & $0.6793(9)$ & $0.9955(10)$ & $0.9425(3)$ & 1 & $0.130(4)$ \\
\hline $\mathrm{O} 3$ & $\mathrm{O}$ & $0.5390(17)$ & $0.0800(18)$ & $0.8923(8)$ & $0.465(4)^{\mathrm{a}}$ & $0.102(6)$ \\
\hline $\mathrm{O} 2$ & $\mathrm{O}$ & $0.7707(17)$ & $0.5413(17)$ & $0.8875(8)$ & $0.535(4)^{\mathrm{a}}$ & $0.126(7)$ \\
\hline O11 & $\mathrm{O}$ & $0.6835(10)$ & $0.0045(10)$ & $0.0577(4)$ & 1 & $0.131(4)$ \\
\hline O5 & $\mathrm{O}$ & $0.5515(9)$ & $0.1034(9)$ & $0.3320(5)$ & 1 & $0.128(4)$ \\
\hline OB1 & $\mathrm{O}$ & $0.7807(18)$ & $0.2180(18)$ & $0.1223(8)$ & $0.465(4)^{\mathrm{a}}$ & $0.109(7)$ \\
\hline OB2 & $\mathrm{O}$ & $0.4514(17)$ & $0.9027(18)$ & $0.8958(8)$ & $0.535(4)^{\mathrm{a}}$ & $0.125(6)$ \\
\hline \multicolumn{7}{|c|}{ Extra framework } \\
\hline $\mathrm{C} 1$ & $\mathrm{Cd}$ & 0.6667 & 0.3333 & $0.911(2)$ & $0.15(2)$ & $0.070(6)$ \\
\hline $\mathrm{C} 1 \mathrm{~A}$ & $\mathrm{Cd}$ & 0.6667 & 0.3333 & $0.929(3)$ & $0.07(3)$ & $0.046(12)$ \\
\hline $\mathrm{C} 2$ & $\mathrm{Cd}$ & $0.8805(15)$ & $0.1207(14)$ & $0.1159(7)$ & $0.073(4)$ & $0.108(8)$ \\
\hline $\mathrm{C} 3$ & $\mathrm{Ca}$ & 1 & 1 & $0.1988(5)$ & $0.324(17)$ & $0.048(5)$ \\
\hline $\mathrm{C} 3 \mathrm{~A}$ & $\mathrm{Ca}$ & 1 & 1 & $0.2362(9)$ & $0.30(2)$ & $0.082(8)$ \\
\hline $\mathrm{C} 4$ & $\mathrm{Cd}$ & 1 & 1 & $0.0889(18)$ & $0.049(4)$ & $0.11^{\mathrm{c}}$ \\
\hline $\mathrm{C} 5$ & $\mathrm{Cd}$ & 1 & 1 & 0 & $0.175(15)$ & $0.091(8)$ \\
\hline C5A & $\mathrm{Cd}$ & 1 & 1 & $0.0318(4)$ & $0.184(8)$ & $0.054(4)$ \\
\hline C6 & $\mathrm{Cd}$ & 0.6667 & 0.3333 & $0.8056(16)$ & $0.065(8)$ & $0.112(17)$ \\
\hline $\mathrm{C} 7$ & $\mathrm{Cd}$ & $0.869(2)$ & $0.736(3)$ & $0.8846(11)$ & $0.029(3)$ & $0.064(11)$ \\
\hline C8 & $\mathrm{Cd}$ & $0.5326(17)$ & $0.0655(17)$ & $0.0023(8)$ & $0.047(3)$ & $0.080(7)$ \\
\hline
\end{tabular}

${ }^{\mathrm{a} O c c} . \mathrm{T} 1=$ Occ. $\mathrm{T} 11=1-\mathrm{Occ} \cdot \mathrm{T} 1 \mathrm{~B}=1-\mathrm{Occ} \cdot \mathrm{T} 11 \mathrm{~B}=\mathrm{Occ} \cdot \mathrm{OB} 1=1-\mathrm{Occ} \cdot \mathrm{OB} 2=\mathrm{Occ} . \mathrm{O} 3=1-\mathrm{Occ} \cdot \mathrm{O} 2$

${ }^{\mathrm{b}}$ Constrained to be equal

${ }^{c}$ Fixed a sudden water loss similar to that observed by Arletti et al. (2013). Hence, $\mathrm{Cd}^{2+}$ may play a double role in such process as follows: (i) it tends to coordinate less $\mathrm{H}_{2} \mathrm{O}$ than $\mathrm{Ca}^{2+}$ due to the smaller radius; therefore, the $\mathrm{H}_{2} \mathrm{O}$ are released earlier at lower temperature; (ii) it exerts more strain on the framework, which starts collapsing already at $400{ }^{\circ} \mathrm{C}$.

\section{Conclusions}

A variety of factors influences the response of natural zeolites to the heating stimuli, complicating the prediction of their behaviour upon dehydration. Because of the wide range of applications where these minerals are used, knowing the structural transformations occurring as a function of increasing temperature is of great interest. In this study, the investigation of a partially exchanged Cd-levyne demonstrated that, although residual $\mathrm{Ca}$ ions are present in the structure, the dehydration behaviour significantly differs from that of the natural material, levyne-Ca. From 50 to $175^{\circ} \mathrm{C}$, a similar water release and associated diffusion path of the EF cations is observed for $\mathrm{Ca}$ - and $\mathrm{Cd}$ LEV. However, from $200{ }^{\circ} \mathrm{C} \mathrm{Cd-LEV} \mathrm{follows} \mathrm{a} \mathrm{different}$ dehydration path. The most relevant outcome is the lack of the structural transformation to the levyne B' topology, as detected in levyne-Ca, and, most important, the reduced thermal stability of $\mathrm{Cd}-\mathrm{LEV}$, which starts collapsing already at $400{ }^{\circ} \mathrm{C}$. This is undoubtedly related to the presence of $\mathrm{Cd}^{2+}$ and to the strain exerted on the framework. It is worth mentioning that a similar behaviour, i.e. reduced thermal stability associated with a pronounced contraction of the unit-cell volume upon heating, was also reported for another zeolite, stellerite, previously exchanged with $\mathrm{Cd}^{2+}$ (Cametti et al. 2019). 
Fig. 4 Reconstructed precession images of $0 \mathrm{kl} *$ and $\mathrm{h} 0 \mathrm{l}^{*}$ layers ( $c^{*}$-axis is vertical) of Cd-LEV collected at $400{ }^{\circ} \mathrm{C}$ and at $\mathrm{RT}$ after rehydration

\section{$400^{\circ} \mathrm{C}$}
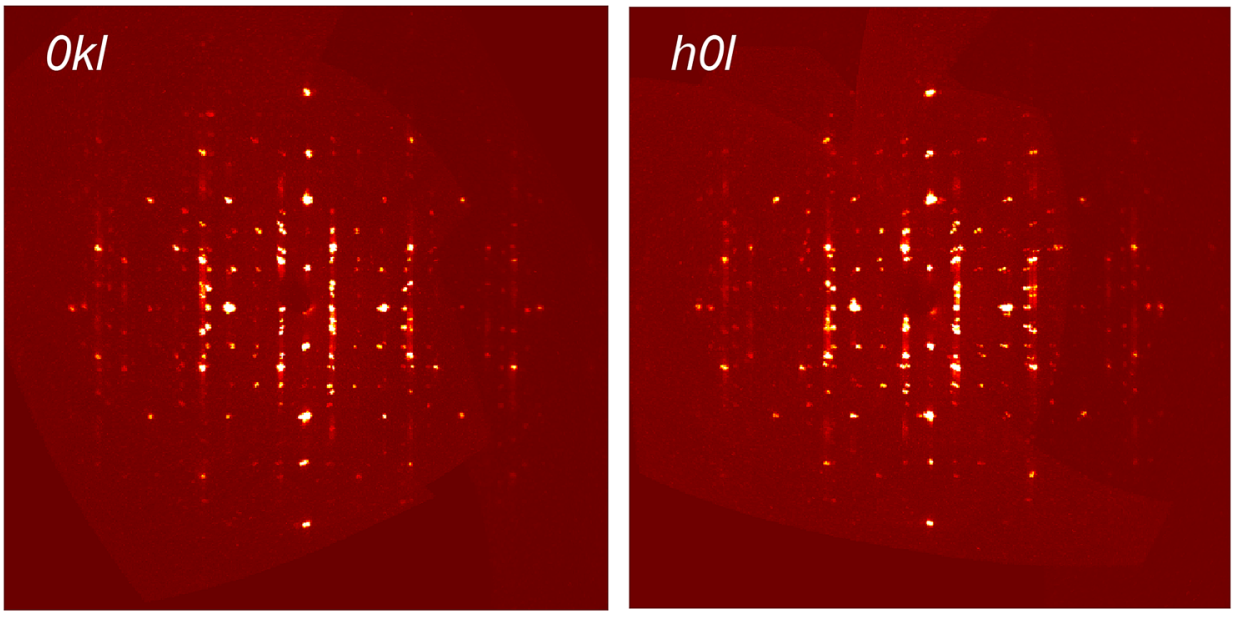

a

\section{RT Rehydrated 21 d}
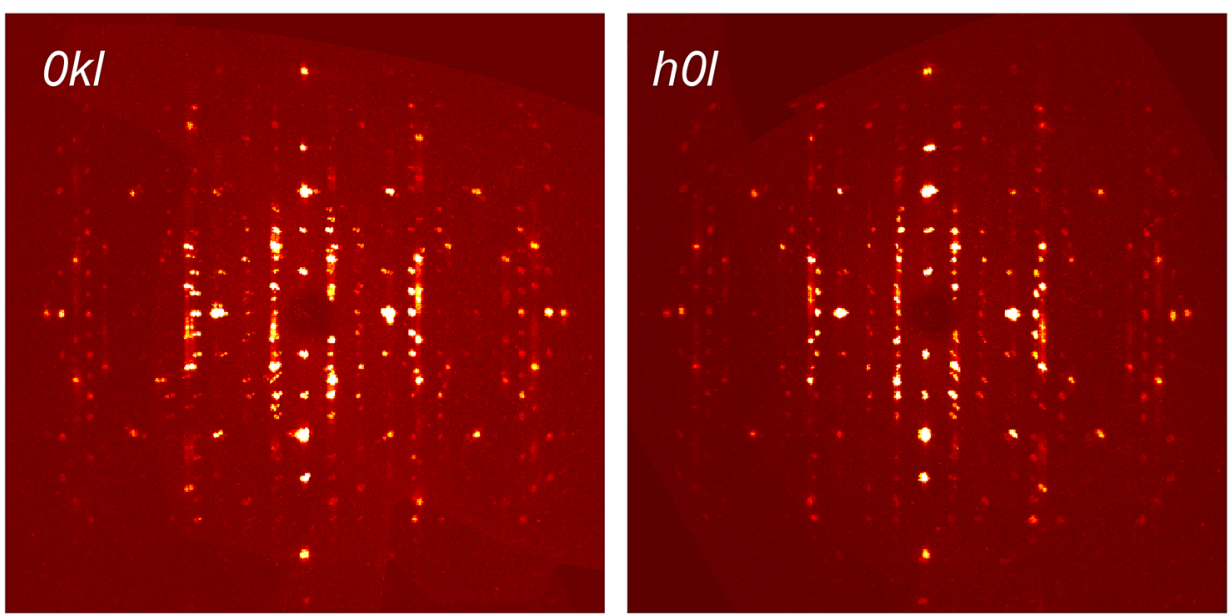

b
Supplementary Information The online version contains supplementary material available at https://doi.org/10.1007/s00269-021-01146-6.

Acknowledgements The author is grateful to Thomas Armbruster who read and commented the final draft of the paper

\section{Author contributions Not applicable.}

Funding Open Access funding provided by Universität Bern. This work received funding from the Swiss National Science Foundation (SNF) under the grant Ambizione PZ00P2 173997.

Availability of data and materilas All data generated or analysed during this study are included in this published article (and its supplementary information files).

Code availability Not applicable.

\section{Declarations}

Conflict of interests The author has non-financial interest to disclose.

Open Access This article is licensed under a Creative Commons Attribution 4.0 International License, which permits use, sharing, adaptation, distribution and reproduction in any medium or format, as long as you give appropriate credit to the original author(s) and the source, provide a link to the Creative Commons licence, and indicate if changes were made. The images or other third party material in this article are included in the article's Creative Commons licence, unless indicated otherwise in a credit line to the material. If material is not included in the article's Creative Commons licence and your intended use is not permitted by statutory regulation or exceeds the permitted use, you will need to obtain permission directly from the copyright holder. To view a copy of this licence, visit http://creativecommons.org/licenses/by/4.0/. 


\section{References}

Arletti R, Vezzalini G, Quartieri S, Cámara F, Alvaro M (2013) A new framework topology in the dehydrated form of zeolite levyne. Am Mine 98:2063-2074

Baerlocher C, McCuscker L, Olson DH (2007) Atlas of zeolites framework types. Elsevier

Ballirano P, Cametti G (2013) Crystal-chemical and structural investigation of levyne-Na. Mineral Mag 77:2887-2899

Bruker AXS, APEX3 v2019.1-0

Cametti G (2018) New topology of levyne B under quasi-equilibrium conditions: A temperature-dependent in situ single crystal X-ray diffraction study. Micropor Mesopor Mater 265:162-171

Cametti G, Scheinost AC, Churakov SV (2019) Structural modifications and thermal stability of $\mathrm{Cd}^{2+}$-exchanged stellerite, a zeolite with STI framework type. J Phys Chem C 123:25236-25245

Cametti G, Scheinost AC, Churakov SV (2020) Structural evolution of Ag-LEV zeolite upon heating: an in situ single crystal X-ray diffraction (SC-XRD) and X-ray absorption spectroscopy study. ACS Omega 5:31774-31783

Cametti G, Scheinost AC, Churakov SV (2021) $\mathrm{Cd}^{2+}$ incorporation in small pore LEV/ERI intergrown zeolites: a multimethodological study. Micropor Mesopor Material 313:110835

Coombs DS, Alberti A, Armbruster T, Artioli G, Colella C, Galli E, Grice JD, Liebau F, Mandarino JA, Minato H, Nickel EH, Passaglia E, Peacor DR, Quartieri S, Rinaldi R, Ross M, Sheppard RA, Tillmanns E, Vezzalini G (1997) Recommended nomenclature for zeolite minerals: report of the subcommittee on zeolites of the international mineralogical association, commission on new minerals and mineral names. Can Mineral 35:1571-1606

Cruciani G (2006) Zeolites upon heating: factors governing their thermal stability and structural changes. J Phys Chem Solids 67:1973-1994

Gatta D, Wells SA (2006) Structural evolution of zeolite levyne under hydrostatic and non-hydrostatic pressure: geometric modelling. Phys Chem Miner 33:243-255

Gatta D, Comodi P, Zanazzi P, Boffa Ballaran T (2005) Anomalous behavior and high-pressure structural evolution of zeolite levyne. Am Miner 90:645-652

Gottardi G, Galli E (1985) Natural Zeolites, vol 18. Springer, Berlin

Merlino S, Galli E, Alberti A (1975) The crystal structure of levyne. Tscher Miner Petrog 22:117-129

Momma K, Izumi F (2011) VESTA 3 for three-dimensional visualization of crystal, volumetric and morphology data. J Appl Crystal$\operatorname{logr} 44: 1272-1276$

Sacerdoti M (1996) New refinements of the crystal structure of levyne using twinned crystals. Jb Neues Miner Monatshefte 3:114-124

Sheldrick GM (2008) A short history of SHELX. Acta Crystallogr A 64:112-122

Sheldrick GM (2015) Crystal structure refinement with SHELXL. Acta Crystallogr C71:3-8

Publisher's Note Springer Nature remains neutral with regard to jurisdictional claims in published maps and institutional affiliations. 